\title{
Nodular hidradenoma: a series of five cases in male subjects and review of literature
}

\begin{abstract}
Nodular hidradenoma, also called clear cell hidradenoma and eccrine spiradenoma, is an uncommon sweat gland tumor, found mainly in adult females. The lesions are usually solitary and are most likely to be found on the scalp, face or anterior trunk. They are usually covered by intact skin, but some tumors show superficial ulceration and discharge a serous material. We describe five cases of nodular hidradenoma presenting as an expanding nodule on the zygoma (case 1), left nostril (case 2), right groin (case 3), scalp (case 4) and cystic lesion on back (case 5). We discuss the clinical and histologic features of this tumor and present a review of the literature.
\end{abstract}

Keywords: nodular hidradenoma, male, series
Volume 3 Issue 2 - 2018

\author{
Sant Prakash Kataria,' Gajender Singh,' \\ Ashima Batra,' Sanjay kumar,' Vinod Kumar,' \\ Pawan Singh ${ }^{2}$ \\ 'Department of Pathology, PT. Bhagwat Dayal Sharma Post \\ Graduate Institute of Medical Sciences Rohtak, India \\ ${ }^{2}$ Department of Pathology, SHKM Government Medical College, \\ India
}

Correspondence: Sant Prakash Kataria, Department of Pathology, PT. Bhagwat Dayal Sharma Post Graduate Institute of Medical Sciences Rohtak, 129, Dharamkunj apartment, Sector- 9, Rohini Delhi-I I0085, India, Tel +919416528216,

Email drkatariasp@rediffmail.com

Received: November 14, 2016 | Published: April 16, 2018

\section{Introduction}

Nodular hidradenoma is an uncommon benign epithelial neoplasm arising from eccrine sweat gland. They commonly arise in head, neck and limbs. ${ }^{1}$ They usually present as well circumscribed lesion with prepondrance in females. They are covered by intact skin or have ulcerative look. They may be solid /cystic/clear cell type. ${ }^{2}$ Histologically, the tumor is composed of lobulated masses located in the dermis and extending into the subcutaneous fat. ${ }^{3}$ It is composed of two cell types: the polygonal cells, whose glycogen content may give the cytoplasm a clear appearance, and elongated, darker, and smaller cells, which may appear at the periphery. The tumor may be solid or cystic in varying proportions. ${ }^{4}$ They may recur after surgical excision but rarely undergo malignant change. ${ }^{5}$

\section{Case report}

We received excision biopsies of different lesions from five male patients, all of which turned out to be nodular hidradenoma on histological examination. The details of the cases is tabulated as under (Table 1). Histologic examination revealed well circumscribed tumor in all cases (Figure 2A). Two types of cells were seen one of the cell type was clear cells with abundant cytoplasm and low-grade nuclei, other one being polyhedral with a rounded nucleus and slightly basophilic cytoplasm. (Figure 2B-2D) Small ductular lumens and focal apocrine change was also observed. (Figure 2B)(Figure 2C) The last three cases also revealed cystic degeneration.

Table I The nodular hidradenoma on histological examination

\begin{tabular}{|c|c|c|c|c|c|c|}
\hline $\begin{array}{l}\text { Sr. } \\
\text { no. }\end{array}$ & $\begin{array}{l}\text { Age } \\
\text { (Years) }\end{array}$ & Sex & $\begin{array}{l}\text { Clinical } \\
\text { presentation }\end{array}$ & Clinical diagnosis & Size & Cut surface \\
\hline I & 62 & Male & $\begin{array}{l}\text { Swelling Right } \\
\text { zygomatous region }\end{array}$ & Eccrine acrospiroma & $\begin{array}{l}5 \times 3.5 \times 2.8 \mathrm{~cm} \text { (Figure } \\
\text { IA) }\end{array}$ & solid grey- white (Figure Ib) \\
\hline 2 & 55 & Male & Growth left nostril & Inverted papilloma & $\begin{array}{l}\text { In multiple pieces } \\
\text { measuring together } \\
2 \times 1.5 \times 0.6 \mathrm{~cm}\end{array}$ & grey- white \\
\hline 3 & 54 & Male & Swelling right groin & Papilloma & $1 \times 0.8 \mathrm{~cm}$ & Cystic cavity filled with pultaceous material \\
\hline 4 & 45 & Male & Swelling scalp & Mole & $1.5 \times 1 \times 0.7 \mathrm{~cm}$ & Grey white with few tiny cystic areas \\
\hline 5 & 29 & Male & Cyst on back & Sebaceous cyst & $2 \times 1.8 \times 1 \mathrm{~cm}$ & $\begin{array}{l}\text { Partly skin covered cystectomy specimen } \\
\text { with inner surface showing whitish } \\
\text { membrane }\end{array}$ \\
\hline
\end{tabular}




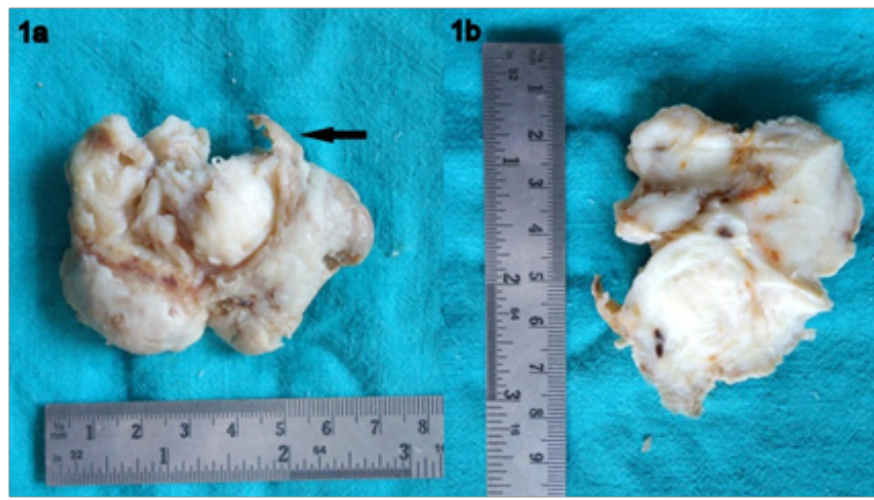

Figure I Resected specimen of swelling in zygomatic region showing a partially skin covered multinodular mass (Ia). The cut surface of the mass was solid grey white. (Ib).

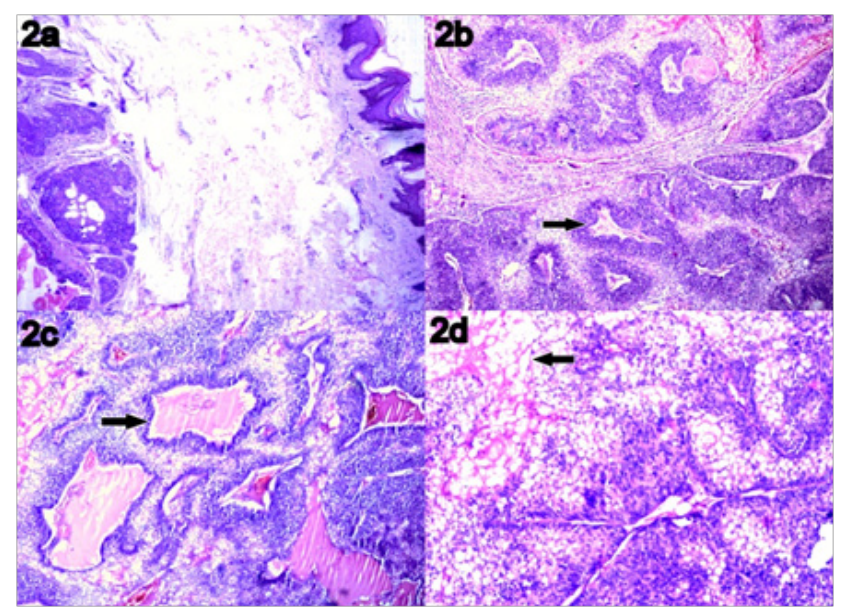

Figure 2 Microphotograph revealing skin covered well circumscribed tumor (2a; H\&E; 40X). The tumor is composed of two types of cells along with cystic spaces filled with eosinophilic material (highlighted with arrow). (2b \& 2c; H\&E; 40X) Higher magnification revealing two types of cells, one of the cell types being clear cells with abundant cytoplasm and low-grade nuclei (highlighted with arrow), other one being polyhedral with a rounded nucleus and slightly basophilic cytoplasm. (2d; H\&E; I00X).

\section{Discussion}

Eccrine acrospiroma is a benign sweat gland neoplasm that occurs as a single mass in the skin with a nodular or cystic structure. ${ }^{5}$ It presents as a solitary, firm nodule with a slight predilection for the head, face, and upper extremities. A review of by Hernandez-Perez and Cestoni-Parducci ${ }^{6}$ revealed a female predominance (1.7:1), with a mean age at presentation of 37.2 years. Sites of involvement were the head (30.3\%), upper limb (25.8\%), and trunk (20.2\%). The overlying skin is generally intact, although ulceration with leakage of serous fluid may be seen. ${ }^{7}$ Histologically, they are well circumscribed and sharply demarcated from the epidermis by Grenz zone. The tumor is composed of solid and cystic spaces. Solid areas reveal the presence of epithelial lobules, comprising of two types of cells. Predominant cell type is the polyhedral cells with more basophilic cytoplasm and the other cell type is round with a clear cytoplasm due to the presence of glycogen. ${ }^{8}$ A preponderance of clear cells, as seen in $\mathrm{CCH}$, is noted in less than one third of hidradenomas. The clear cells contain glycogen and periodic acid-Schiff- positive, diastase-resistant material, but no lipid. $^{9}$ It has been suggested that the clear cells are a metabolic variant of epidermoid cells, rather than a peculiar form of tumor differentiation. ${ }^{10}$ Duct like structures are often present, some of which resemble eccrine ducts, while others consist of slit like spaces lined by concentric layers of squamous cells. It has been suggested that the cystic spaces form as a result of tumor cell degeneration. ${ }^{3}$ The intervening stroma varies from delicate vascularized cords of fibrous tissue to dense hyalinized collagen. Myxoid and chondroid stroma are less frequent. ${ }^{9}$ Wide surgical excision is the mode of treatment to minimize the risk of recurrence, with histological confirmation of the same. ${ }^{1,2}$ Malignant transformation is rare; in one review, $6.7 \%$ cases were malignant and were histologically characterized by nuclear atypia, necrosis, and abnormal mitoses. An aggressive course with widely disseminated disease and death has been reported. The histologic appearance does not always predict the behavior of clear cell hidradenoma. ${ }^{6}$ The differential diagnosis of clear cell tumors in the dermis includes metastatic disease and primary skin tumors with follicular differentiation, sebaceous differentiation, or sweat gland differentiation. $^{7}$

\section{Conclusion}

This report highlights the salient histologic findings that distinguish nodular hidradenomas from other adnexal tumors and emphasizes the benefit of complete local excision to prevent recurrence of these tumors.

\section{Acknowledgements}

None.

\section{Conflict of interest}

Authors declare that there is no conflict of interest.

\section{References}

1. Dubhashi SP, Sindwani RD, Kumar H, et al. Nodular hidradenoma over the chin: A rare presentation. Int J Health Allied Sci. 2014;3(4):248-50.

2. Upreti L. A case report of Nodular Hidradenoma on palm.

3. Elder D, Elentisas R, Ragsdale BD. Tumors of the epidermal appendages. Histopathology of the Skin. Philadelphia: Lippincott-Raven; 1997. p. 747-803.

4. Weedon D. Skin Pathology. Edinburgh, New York: Churchill Livingstone, 1997. $755 \mathrm{p}$.

5. Gatti A, Di Meo N, Trevisan G. Dermoscopy of eccrine acrospiroma masquerading as nodular malignant melanoma. Acta Dermatoven APA. 2010;19:23-5

6. Hernandez-Perez E, Cestoni-Parducci R. Nodular hidradenoma and hidradenocarcinoma: a 10-year review. J Am Acad Dermatol 1985; 12:1520 .

7. Volmar KE, Cummings TJ, Wang WH, et al. Clear Cell Hidradenoma A Mimic of Metastatic Clear Cell Tumors. Arch Pathol Lab Med. 2005;129:e113-6.

8. Pushpa B, Duraisamy K, Gayathri. Study on Morphological Features of Nodular Hidradenoma. Journal of Evolution of Medical and Dental Sciences. 2015;4:9140-4.

9. Weedon D. Tumors of cutaneous appendages. Skin Pathology. 2nd edn. London, England: Churchill Livingston; 2002. p. 859-916.

10. Ohnishi T, Watanabe S. Histogenesis of clear cell hidradenoma: immunohistochemical study of keratin expression. J Cutan Pathol. 1997;24(1):30-6. 